ISSN 2657-327X

\title{
“It's scary here." Haunted landscape as a research tool to look into post-expulsion landscapes
}

\section{Karolina Ćwiek-Rogalska}

(Institute of Slavic Studies, Polish Academy of Sciences)

ORCID 0000-0001-6142-5609

\begin{abstract}
The article deals with the idea of "haunted landscape" as a research tool in analyzing post-expulsion landscapes. I propose a new perspective on analyzing narrations concerning expulsion and resettlements of lands where a drastic demographic change took place. I use existing research connected with the idea of Jacques Derrida's hauntology, as well as other analytical sources dealing with folktales of different regions. As material for analysis, I propose various records from ethnographic research conducted in the Czechoslovak borderlands, stored at the Institute of Ethnology of the Czech Academy of Sciences, concerning the space of a "traditional house" and the new settlers' views on their new home.
\end{abstract}

Key word

haunted landscape, borderlands, post-expulsion landscape, hauntology, Czechoslovakia

KONRAD

Wyście pomarli. Trupy i upiory. Nędza duszy! MASKA 19 Tyś bogacz. KONRAD I przyszliście mnie kraść. MASKA 19 To jest idea. Napisz to jako artykut.
KONRAD

You're dead. Corpses and ghosts. Misery of the soul! MASK 19

You're a rich man. KONRAD And you came to rob me. MASK 19 That's an idea. Write it as an article.

Stanisław Wyspiański, Wyzwolenie [Liberation], lines 1904-1907.1

1 Translated by Michał Rogalski. 


\section{Introduction}

As Owen Davies provocatively stated in the very first sentence of his social history of ghosts, "England has long had a reputation for being haunted" (Davies 2007, 1). It is possible to say the same about most of the countries in Central-Eastern Europe. Why? Davis argues why England is so haunted: "It is primarily a consequence of our [English] religious, social and cultural development over the last 500 years" (Davies 2007, 1). And hardly any European region has undergone more turbulent and eventful development than Central Europe has, so why not use that as an excuse to investigate the problem of what haunts the landscapes of this area?

I find it tempting to use hauntology as a research method since "spectrality seeks less to take the place of other approaches or concepts than to supplement them with another dimension ... by offering a new, truly 'other' perspective" (del Pilar Blanco and Peeren 2013, 21). It seems that it is worth incorporating as part of landscape studies. Hauntology can be seen primarily as a rather Western-phenomenaoriented method (del Pilar Blanco and Peeren 2013, 19), but I argue that it is also possible to use it in cases of Central European origin. Especially when we keep in mind that writing from a perspective other than the mainstream is always a kind of writing about ghosts (Gordon 2008, 17).

My article aims to answer questions about the possibility of using the concept of "haunted landscape" that I want to propose as a new analytical tool in landscape studies, in particular, as applied to the case of the forced migration of Germanspeaking inhabitants from Czechoslovakia after 1945 and the resettlement of the socalled Czech borderlands (pohraničí). My research questions are as follows: how can we understand "haunted landscape" as a separate phenomenon? Where does it come from? What does it mean that a landscape is haunted? What is the force haunting a landscape? What places can be haunted? For illustration I use oral sources and fieldwork materials collected by Czech ethnologists between 1981 and 1983 in different parts of the borderlands, since they are richer in their description of the post-war period than newer research is, and also because of their relative temporal proximity to the post-war years. Using older research can raise other questions, since it is not only about looking into the problems of the interviewees but also of the interviewers. Examining ghosts is always examining our own ghosts (Bell 1997, 831).

Moreover, using "haunting" and "ghosts" as valid categories of analysis can not only help us to see other perspectives, give voice to usually voiceless entities (such as landscapes), or narrations that are not mainstream, it can, as was pointed out by American media scholar Jeffrey Andrew Weinstock, tell us something about our society's "hopes and desires, fears and regrets-and the extent to which the past governs our present and opens or forecloses possibilities for the future" (Weinstock $2004,8)$. Since the Czech borderland seems to be a region governed by the past, it is worth examining to what extent it proves the point of being "haunted." 


\section{What is a "haunted landscape"?}

When we are dealing with such terms as "haunted landscape" or "ghost landscape," they function in academia more as metaphorical nicknames to describe empty or wasteland landscapes than as research terms. For example, Tina Rosenberg, in her acclaimed book on the political transformation of Central-Eastern European countries, uses the term "haunted lands"; however, she does not operationalize it (Rosenberg 1995). So, to begin with, we should ask: what is a "haunted landscape"? The term is present in today's scholarship in different forms. The easiest is to say, like the literature scholar María del Pilar Blanco, that a haunted landscape is a landscape where a haunting takes place (del Pilar Blanco 2012, 1). Although it sounds rather common-minded, del Pilar Blanco continues that "haunting ... is linked to doubt because it depends on that crisis of perception expressed in questions surrounding a landscape ('what is there that I cannot see, but I nevertheless sense is there?'). Doubt is also a reminder of the unfinished business that is experience and its necessary open-endedness: It indicates a site of action that does not know its outcome or even its purpose" (del Pilar Blanco 2012, 25). A haunted landscape is a kind of landscape that forces us to doubt what we see, if we see what we are claiming that we see, as well as a landscape that exhibits some incompleteness of processes, a rupture in activity that was developing there.

There is one crucial thought when it comes to what example to choose to illustrate the issue: there are some particular landscapes that are more haunted than others. So, where do they come from? Scholars mostly agree that "haunted" places are to be seen where something "has vanished, what has been lost, what has gone awry, and what remains unresolved through the passing of the generations" (Maddern $2008,363)$. It originally comes from Jacques Derrida's thought of ghosts emerging from ruptures and cracks when something is "out of joint" (Derrida 2016). So that's from where ghosts appear: from unstable, unfinished, or deteriorating spaces.

But what does it actually mean that a landscape is haunted? There are many definitions of "haunting" or "visitation," another term that is used when one tries to describe how a ghost appears somewhere. They are in accordance with one another as well as with the basic Derridean principle that "haunting" is an action that disrupts "order and stability" (Trafton 2013, iii). It obliges us to ask questions about the nature of reality, since our "experience of reality is itself always already haunted by the profound limitations of human subjectivity and the incomprehensible vastness in the reality beyond" (Trafton 2013, iv). Reality is a social construct. But unlike postmodern philosophies, such as Slavoj Žižek's position (Žižek 1999, 64-66), there can be more beyond it, we just do not know what. "Ghosts" are an immanent part of our reality as signs of what transgress it at a given moment, we just do not know it is happening until the "haunting" occurs. Through "haunting" one can see the limitations of reality and, in this way, can be a way of understanding how 
reality works. Scholars also refer to the point that haunting is an unwanted activity (Maddern 2008, 365; see also Hetherington 2004, 157-173), and it is a persistent activity that takes place in one given place (Davies 2007, 3).

What is the force haunting a landscape? It is impossible to understand "haunting" as such; therefore, we need a figure of a "ghost" that haunts (Trafton 2013, 12). It is not necessarily a "ghost" as in an unnatural entity or some kind of supernatural being. As has already been shown by hauntologists, ghosts could be understood as figures or concepts that help us deal with marginalized subjects and voices (see Bell 1997; Wolfreys 2001; del Pilar Blanco 2012; Marzec 2015; Derrida 2016). To use these categories is also to try to "represent the unrepresentable" (Holloway and Kneale 2008, 297).

What places can be haunted? Although Owen Davies gives us a comprehensive overview of places that are haunted more frequently than others, it does not exhaust all the possibilities. In the second chapter of his book, entitled "The Geography of Haunting," he lists such places as "insides" (such as houses and even particular rooms in a house), "landscapes of death" (such as churchyards, gibbet sites, and battlefields), "treasure sites" (where something precious is hidden and guarded), "water" (as liminal spaces that are between known and unknown, civilized and wild; it is also connected to other liminal spaces such as bridges or crossroads), "mines" (because the nature of the work of a miner is dangerous), but also "cities" (especially in the modern era) and "tourist sites" (Davies 2007, 47-64). ${ }^{2}$ What links all those places is the fact that "ghosts" apparently appear where their mortal body had died; hauntings are more frequent in such places, as well as in different liminal spaces and-what is maybe the most interesting among Davies' observations - where the landscape has changed because of industrial revolution, melioration, draining, and other similar process. Such change of the landscape makes haunting no longer comprehensible: it is hard to understand why ghosts haunt such place (Davies 2007, 46; see also Richardson 2003, 17-31). Nonetheless, it is still clear that they haunt.

\section{Materials}

Interest in hauntology relates to the post-modern disbelief in the easy versions of known stories (Weinstock 2004, 3). Therefore, I would like to analyze materials collected by Czech ethnologists in 1980s. In this paper, I will use materials stored at the archive of the Institute of Ethnology of the Czech Academy of Sciences. ${ }^{3}$ Investigating materials collected by somebody else, especially in a "personal" discipline

2 As he puts it, "the landscape is still full of ghosts but you are better off looking for them on the tourist trail than on a trek through the countryside" (Davies 2007, 64).

3 I would like to thank Marcela Suchomelová from the Institute of Ethnology of the Czech Academy of Sciences for her help with finding the materials. 
like ethnology, means looking not only into the achieved results but also into the methods, aims, and personal thoughts of the researchers who collected them. Therefore, this kind of research is a kind of double ghost-hunting: firstly, I am looking into ghosts that haunted landscapes researched by Czech ethnologists and, secondly, into these researchers' objectives, so they seem nowadays like different kinds of ghosts. Among the materials archived at the institute are their fieldnotes, working materials, and the questionnaires used during their fieldwork.

The materials that I have analyzed come from very wide-ranging fieldwork which had different aims. ${ }^{4}$ It was led by Iva Heroldová, one of the most famous Czech ethnographers interested in national relations in the borderlands. It took place from 1981 to 1983 in different parts of the borderlands. I will use data from three places: Osoblaha in the Bruntálsko region, Staré Město in the Bruntálsko region, and Branná in the Šumpersko region. They are stored in the archive as written questionnaires-although there are some remarks about tapes with recorded interviews, none were found there. The research was aimed at the study of traditional architecture, but in a questionnaire named "Traditional House" (Tradiční dùm), among 86 different questions, as many as 19 concerned connections between new settlers and old inhabitants, their housing habits and practices just after the war, and in what way German property was included into post-war economic and social reality. Along with each questionnaire, there was also a separate one concerning individual interviewees, called "Data about informant" (Údaje o informatorovi), where 13 questions out of a total of 57 concerned his/her views on German property left behind and memories about German inhabitants. Some of the materials from this fieldwork were used in collected works, such as Etnické procesy $v$ českých zemích (Ethnic processes in the Czech lands), but were never used to actually investigate the situation of cohabitation of Czechs and Germans in the borderlands or the settlers' treatment of the remnants of German-speaking culture.

\section{The "haunted landscape" of the Czech borderlands}

Although the research that I am dealing with was done during the times of a socialist regime in Central Europe, some remarks from late capitalism landscape researchers seem to be of use here, mostly because they show how "ghosts" change our vision of time as a linear phenomenon that evolves into one direction of so-called "progress” (Benjamin 1999; Maddern 2008, 367; O’Callaghan, Boyle, and Kitchin 2014; López and González 2014). It is also worth addressing because of the turning point

4 Therefore I decided to quote whole questions: they were usually long and detailed, enlisting possible answers in case an interviewee could not answer them with his/her own words. A particular attitude toward the researched subject is sometimes seen in their construction: for example, in the question concerning the cohabitation of new settlers and old inhabitants, there is a suggestion that the Germans could have done some kind of harm or sabotaged a farm that was previously theirs. The question of the image of German-speaking inhabitants in the questionnaire is a separate one and should be further investigated. 
for when the "haunted landscape" of the Czech borderlands took place: the expulsions that started in 1945 and can be seen as a start of an immense and still ongoing crisis in Czech society (Černý, Křen, Kural, and Otahál 1990).

According to Žižek, there is no other reality than the one that we are trying to "cover up." Through this process we experience reality, and in this way reality is "symbolically constructed." What is interesting, nonetheless, is that there is always some small space between the event and its recording ("covering up")—which is more intense in times of crisis, because the symbolic frame that is built by the given group is "out of joint." The symbolic frame no longer reflects our "covered up" reality (Žižek 1999). The new, post-war reality of the borderlands is unified by the construction of new symbolical fictions from the leftovers of persisting but muted history (see O'Callaghan, Boyle, and Kitchin 2014, 124). Why is there a need for ghosts in this post-expulsion landscape, why has it become haunted? New settlers came to regions that seemed strange to them, and they needed something to define them in opposition to the "strange," thus "uncivilized," lands and remains of a culture that was described as "foreign." Therefore this strategy seems to be similar to what David Punter and Glennis Byron point out about the English literary Gothic: "[it] always remains the symbolic site of a culture's discursive struggle to define and claim possession of the civilized, and to abject, or throw off, what is seen as other to that civilized self" (Punter and Byron 2004, 5). The settlers built their new order, ejecting what seemed to them "barbaric." It is worth noting that in the context of the English literary Gothic, "ghosts" were accused of being a "barbaric heritage" (Trafton 2013, 30), and the "German" culture of the borderlands seems to be a distant relative to this claim.

\section{Ghost stories of the borderlands}

As researchers who are dealing with the subject of literary and folk ghost stories argue, there are several indicators characteristic of this kind of storytelling. Among them, one of the most important is the lack of logical explanation for events (Briggs 2015, 177). It is not necessarily the case that the unnatural beings that do the haunting in these types of works are the dead returning to our world. These are creatures who inhabit the world according to their own rules. Rules in the world of ghost stories are not "rational" but rather set "inside a kind of imaginative logic in which the normal laws of cause and effect are suspended in favor of what Freud termed 'animistic' ways of thinking, in which thought itself is a mode of power, in which wishes and fears can actually benefit or do harm" (Briggs 2015, 178).

"Strangeness" and "ghostliness" are achieved through the impression of truth, giving the receiver the possibility of feeling a pleasant thrill-like we sometimes have remembering an unhappy past event, turning it into an anecdote. It should be maintained within certain decorum, but the mechanisms of "ghostliness" should 
be kept in the shadows. Moreover, the stories should be contemporary to those who relate it (James 1929). On the other hand, it is important to remember that ghost stories are a genre where darker aspects of human nature have a voice: "ghost stories often deal with the most primitive, punitive, and sadistic of impulses, revenge being one of the commonest motifs present in the form" (Briggs 2015, 182).

Having that in mind, one can ask if a ghost story as a narrative scenario for storytelling about one's experiences after the war in the borderlands, during expulsions and the resettlement process, is a proper choice? I would argue that it is, because all of the elements that are characteristic of ghost stories are also characteristic of the stories that are told by the new settlers and inhabitants who were not expelled. It is a story filtered and told by the experiences of the researchers who collected the questionnaires, so we do not get them in first-hand form. They are made more "literary" and, hence, more open to interpretation as literary sources.

\section{Uncanniness}

As historical and demographic research shows, the re-colonization of this region was not successful (von Arburg and Staněk 2010). Therefore, the resettlement of the borderlands that started already in 1945 bears the marks of "uncanniness." As Renée Bergland argues, the uncanny is "the unsettled, the not-yet-colonized, the unsuccessfully colonized, or the decolonized" (Bergland 2000, ii). Cutting off German-speaking legacies in the borderlands also meant orientating the landscapes of the region toward the future. Such activity relates to a historical amnesia and leads to the feeling of timelessness (Tuan 2013). Without "ghosts" it is impossible to speak about the past of the land and it is impossible to settle it. There is always something "uncanny" that disturbs it.

"Uncanny" (Unheimlich) literally means "un-homely" or "unfamiliar." It is a fitting name for spaces that were deprived of their status as homelands through expulsions and new resettlement strategies, which were often-as in this case-not successful. The "uncanniness" of the borderlands is also visible in what the interviewees repeated. Like in Freud's classic narration about Unheimlich, where the researcher wanders in narrow Italian streets and starts to feel bothered, the repetitions of "events, images and localities is one of the recurrent motifs of the uncanny" (del Pilar Blanco and Peeren 2013, 396). So, if the feeling of "uncanniness" also accompanies individuals who are dealing with "haunted landscapes," it is possible to widen the Freudian analysis of "unheimlich" to something that is present in the experience of haunting. Landscapes become "haunted" (or "spectral," as del Pilar Blanco and Peeren propose to call them) because of repetitive observations concerning the same things. 


\section{What is haunted}

What kind of "haunted" spaces are there in the analyzed material? Although what Davies observes is right, so the "insides" of houses and farm buildings are in large part spaces of "haunting," there are other places that seems to be "out of joint," "out of order" (Derrida 2016), and where "something is not right" (Sendyka 2014). When it comes to houses, it is mostly about colors and decorations, as well as pieces of furniture. What concerns farm buildings is mostly the presence or lack of animals. Not only can given rooms be haunted, as Davies argues, but given objects inside the house can be haunted too. Moreover, a whole village or town could be seen as haunted. Also, a landscape as such may seem to be "out of joint": there the perception of weather conditions seems to be especially important. Let's try and analyze the materials to see what places are truly "haunted" in the Czech borderlands.

\section{"Outside"}

Throughout the questionnaires, it is noticeable that some places seemed "stranger" than others to the settlers, and there the possibility of haunting begins. What catches the eye in the beginning is question 8 from the "Traditional House" questionnaire. It reads as follows: "In what state was the house when you got it? In what shape were the farm buildings?" Among the answers are:

\footnotetext{
"damaged, they had to insert glass in windows, there was no roof" (Moldavian expatriate, woman, Osoblaha); "the house-the roof was full of holes, the facade was destroyed, the stable-very destroyed" (Czech man, Osoblaha); "destroyed windows, roof, the facade was destroyed by shrapnel” (Czech man, Osoblaha); "in bad shape” (Czech man, Staré Město); "the house was in very bad shape." (Czech man, Branná)
}

The omnipresent destruction is evident: houses are generally in bad shape, being more ruins than habitable buildings. The signs of war are still visible ("facade ... destroyed by shrapnel"). It is important that most of these answers concern facades: first view that was to be seen by settlers after they came to the borderlands. What is "inside" is not yet visible in these answers.

It should also be noted that there are no remarks about who did this to the villages and towns that were meant to be re-settled. Question 31 from the "Data about informant" questionnaire about the activity of so-called "gold-diggers" (looters) brings some answers. The answer that "most of the houses were plundered" (Czech woman, Branná) shows that there were some forces behind the state of the village, though not visible-more like invisible forces that brought catastrophe and then vanished. Also, those who came later complained that "in the house they bought there were a lot of things missing-the first settlers took everything left from the 
houses" (Czech woman, Branná). "Gold-diggers" and "first settlers” are invisible, yet powerful creatures who left their marks in the landscape but are no longer there.

It is interesting that these remarks were made without further consideration concerning what to do-they were seen as past, as something that was presently no longer seen, and the settlers could say proudly that they did what had to be done and adapted as necessary. Only one interviewee, immediately after stating the bad shape of the property, said "[the house was] in very bad shape; everything needed to be adapted and remade" (Czech man, Staré Město), while another added that "it was necessary to fix it" (Moldavian expatriate, woman, Osoblaha). Adaptations and renovations done by the settlers could be called "cautious." As one of the interviewees stated, "a new facade [was constructed] in 1968 (but only because the previous one was in bad condition)" (Slovak woman, Osoblaha). There was nothing to be done except the most urgent things. The power of destruction was more present than the need to adapt or fix what was left behind. We do not, as in a ghost story, know the precise mechanism standing behind the destruction-we only know that it took place.

\section{Treasure sites}

There are, however, some places that are almost "tangible" traces of these-and other-forces. In the settlers' narrations, we can distinguish another similar category of "haunted space" in accordance with Owen Davies remarks. It is a specific kind of "treasure site." The stories of German-speaking inhabitants hiding valuable things by burying them are frequently mentioned by the interviewees as proof that "the Germans" believed they would shortly return. As one of the interviewers noted, "They [Germans] believed they would come back. It is evidenced by their burying valuable things. Apparently, they were often discovered" (expatriate from Romania, woman, Branná). The same was mentioned by another interviewee: "Hidden things in houses, buried things" (Czech man, Branná). Beside these marginal and maybe more anecdotal mentions, we can find also more elaborated stories, where interviewees were trying to make sense of this activity of "burying things." As was noted by one of the researchers in the margin of the questionnaire of a Czech woman in Staré Město:

[The wife of a German school director] asked her to prevent them being expelled, [she] answered that she can't, and she doesn't want to; there were rumors that the director's wife was able to shoot and at night buried the corpses. [She] allegedly took out some permission and she came back for some time and she even tried to bury things from the farm. (Czech woman, Staré Město) 
It can serve as a kind of explanation of how the "supernatural" works, yet it lacks more dramatic details. It also works in this "kind of imaginative logic" that I was describing when it comes to ghost stories. It gives the story a pleasant thrill, and expulsion is shown as a benefiting opportunity to get rid of a "strange" and dangerous being that could not be helped: she seeks revenge but could not find any. The German teacher's wife is dangerous as such but is at the same time harmless. She could not do any harm to the new settlers.

The haunting-yet not physical—presence of previous inhabitants connected with "burying" things sometimes brings to mind detective work. It also helps to uncover who was there before the settlers came: "The house was occupied by a shoemaker. The informant found a buried bottle of nails... [but] he never met any Germans." (Czech man, Staré Město)

\section{Weather}

Unfriendly, haunted neighborhoods are discernible in the new settlers' opinions about the weather, climate, and landscape as such. As one of them stated, one of the most difficult things to get used to was the "different character of the landscape, at home they wore any shoes from spring until autumn, here they couldn't go barefoot even in the yard. Different kinds of plants-they couldn't grow their own hops, it bothered her husband" (Czech Volhynian woman, Osoblaha). The climate was much harsher there than where the new settlers came from, especially for so-called "expatriates" from Volhyn (Ukraine), Romania, or Moldova. They were afraid of the conditions: "The climate [was difficult]. She came from the south, where there was almost no snow" (Czech woman, Staré Město); "It was colder here" (Slovak woman, Branná). The cold as a characteristic mark of the borderlands is reminiscent of places that are "haunted," dead. Those who come back from the dead are usually described as colder, since there are no longer any organic fluids in their bodies. In this case, the whole land is seemingly colder, since it lacks the circulation of the forces that previously gave it life.

\section{Villages of ruins}

So what did places like Osoblaha, Staré Město, and Branná look like at the time of the settlers' arrival? It is striking that the modes of description that we can distinguish are like narrations familiar from ghost stories. The description of a ruined, empty "ghost town" is dominant. Each house that is allocated to settlers or is taken by them has been previously partially demolished: this repetition is a sign of "unheimlich" visible in the materials. Repeated stories about destroyed houses that seem to be like one another and yet feel "strange" to newcomers are a sign of haunting. Answering question 50 from the "Traditional House" questionnaire, 
"Who were your neighbors at the time [of your settlement]?", one of the interviewees claimed that "it's hard to say, in destroyed Osoblaha everyone and no one" (Czech woman, Osoblaha). It shows us a space that is so empty that it is hard to set any borders. The same is even better visible in a report precisely noted by the interviewer: "In [village name] I shout to the neighbors and they hear me on the other hill, here he wouldn't be able to hear me if he were behind his house" (Czech man, Osoblaha). Disturbances when it comes to the border affects how the space is used (that is: communicating with neighbors), and traditional behaviors cease to make sense there. Answering a question about the state of their house, another interviewee said that it was as bad "as all of them" (German man, Branná). But we do not have to guess, another settler was more explicit: "Because it was just after the war, the situation was totally bizarre, the village was practically totally ruined" (Czech woman, Osoblaha). She used the Czech word "zvláštní" (bizarre) to set the mood: the world the new settlers came into was the reverse of what they were used to. Instead of homes ready to be settled, they came to a land of ruined houses. It worried them: "She was mostly concerned with the state of Osoblaha, it was 'cut off' from the world" (Slovak woman, Osoblaha). It is a perfect setting for ghost stories: no one there can hear screams for help.

The settlers liked to emphasize the bad shape of the village as such. One of them stressed that: "The village was in very bad shape, without electricity; there was no culture here" (Czech woman, Osoblaha). We find a similar idea in another interview: "It was so sad here, there was no culture here" (Czech woman, Branná). It is interesting that this lack of culture indicates the lack of the possibility of entertainment (culture understood as access to a theater, cinema, library, culture house, etc.), but it also places this narration in the framework of "our culture" vs "their lack thereof," as I was describing in the case of the English literary Gothic.

The character of a far away, empty village is very well described by one of the interviewees. Among the questions we find one that concerns the feelings of new settlers (question 33, "Data about informant"): "What was in the beginning hard to get used to for you (or your family, group) (character of the landscape, residential form of the village, character of the farm work, work conditions, contact with original inhabitants, with different groups of settlers, etc.)?" What is worth noting is that there are auxiliary questions in case an interviewee had problems with listing anything. Answering this question, one of them, a German woman that was not expelled, said that it was hard to get used to "this loneliness. It was all empty" (German woman, Branná). But was the picture of an empty village actual? Were there truly any ghosts emerging from the cracks of ruined houses? Before I answer that question, I would like to examine "inside" spaces that seem to be haunted. 


\section{"Inside"}

When it comes to describing what was in the houses, there are several things that seemed to be strange to the new users of these spaces. One interviewee said that "[The house] had been plundered, empty; there was no electricity" (Czech man, Branná). The lack of electricity, modern light, is one of the signals that there is something not right here, that the village has no connection to the outside world, moreover that it is dark and unfriendly. Even if there were some things consider to be archaic, not modern, they could still be of use. One of them was bread stoves. In most cases they were still in place and helped some settlers feel at home. Others stressed that they were unable to use them because they could not bake their own bread.

It is worth looking into the ways interviewees depicted the general "insides" of the houses. Question 57 of the "Traditional House" questionnaire concerns the furniture: "In the case that the house was still furnished at the time of your arrival, what elements of the furniture and the rest of the facilities did you use, for example, for some time? What elements of the furniture and the rest of the facilities that were previously German do you have to this day? What elements of the furniture did you not use and why?" The answers provided to interviewers varied. Some settlers did have furniture owned previously by German-speaking inhabitants, such as:

"an old cupboard, a bed-informant didn't use them, he had his own furniture" (Czech couple, Staré Město); "he does not know if it was left by the Germans or previous Czech settlers, he used a sofa and a bed for some time" (Czech man, Staré Město); "in the hall there was 'Tyrolian' furniture: three corner benches, a table with a foot rest, chandelier, book cases." (Czech woman, Staré Město)

The furniture is "old" or bare, some marks of being "foreign" ("Tyrolian"), and there is some feel of "strangeness" in it-it is not even very clear who the previous owner was. Moreover, the pieces belong not to the most useful but are rather of luxurious character (cupboard, chandelier). Most of the interviewees stressed that they did not use it or keep it: "They took everything out of the house and brought it to a stockroom for other settlers who came here without furniture" (Czech man, Staré Město); “They did not keep anything, they wanted to have only 'their' ('our') furniture" (Czech woman, Branná).

\section{“German rooms": practical and decorative things}

As Davis has stated, even particular rooms in a house could be haunted. It is interesting that most of the interviewees answer in detail the question about the look of 
the interior of their house. Question 44 of the "Traditional House" questionnaire concerns that issue: "With what furniture and other facilities were particular rooms equipped? What were the floors covered with? How were the walls of the rooms painted? What were the decorative objects in particular rooms, such as paintings, pictures, crosses? What else? How were the decorative objects spaced?" These stories reveal a similar pattern of things disappearing with time. Some answered that "there were no decorative objects-they were dismantled before [the family] came here" (Czech man, Osoblaha). Others emphasized that they used things that were in place only for some time as the only available option: "The informant used to live with German furniture for a year, in her room she had a sofa and a wardrobe" (Czech woman, Staré Město); "Some possessions left by Germans had indeed been there, but they did not keep them" (Czech woman, Branná). But there are also curious stories about "German rooms" as places that the settlers did not want to go: "The informant doesn't know [what the Germans' rooms looked like], he has never been there" (Czech man, Staré Město). Some spaces occupied by Germans were intentionally left unaccessed.

What was left were some decorative objects of no precise use:

\footnotetext{
"Piano left by Germans, nothing else" (Czech woman, Osoblaha); "there was a picture left-photography" (Czech man, Staré Město); "the furniture was given to the National Committee by the informant. In storage beneath the stairs, there were two printed pictures with hunting motifs left by Germans" (Czech woman, Staré Město); "there was only a decorative porcelain plate left, it is in the living room as a decorative object in a display cabinet." (Czech man, Staré Město)
}

Some of them act as trophies and are placed by the new owners where they can be seen (in a display cabinet), others are stored not to be seen (beneath the stairs).

What is the most haunted in the rooms are the colors. In the questionnaire "Traditional House," there was a direct question (55) concerning that: "Was there, in the house, in particular rooms, paintwork left by Germans? How was it? Did you change the decoration in the rooms? How? Did you try to decorate the house according to your taste? What did that mean at that time? How long did you decorate the house and particular rooms like that? Why did you stop? Did it just stop like that, or was it because of the lack of materials or utilities?" It was one that got the most frequent and longest answers. "Distinctive" or "vivid" were the gentlest descriptions of "German" paintwork. Others called it more "dark" and "unusual":

"Dark red and a purple base and big roses made with pattern in the living room, a dark green base and colorful flowers, as well as golden intersected lines" (Czech man, Staré Město); "big flowers made with pattern, he doesn't remember the colors" (Czech man, 
Staré Město); "rooms were painted in dark colors, glaring combinations of patterns." (Czech man, Osoblaha)

"Dark" colors are seen as something unusual, different, ghostly. They seem to be scary. The shapes that were painted intimidated the settlers.

It was also described in terms of mystery:

"In the course of painting, the original paintwork peeps out: in the living room strong black lines and blue flowers, in the kitchen purple flowers in squares, vivid colors" (Slovak woman, Osoblaha); "he happened on the original paintwork while working on the electricity, ... colors-colorful, grave, mainly blue, no roller, but patterns with a use of a paper pattern; ... he painted over it himself." (Czech man, Branná)

The paintwork was no longer something that was just there when they came. It has its own strange power of bothering settlers: it "peeps out," reminding them of the previous owners, often during activities we would call "modernizing" the space, such as adaptations, wiring, or painting the walls. It is like a ghost of the past haunting the "modernized" space of the "insides."

\section{Farm buildings}

What is visible in the stories told by the interviewees about their first encounters with "German" farms are the stories about farm animals or lack thereof on the farms they were meant to "get" or "have allocated to them." There were several detailed questions about farm buildings and animals per se included in the questionnaire. Some of them concerned facilities like pigpens or stables-others concerned animals as such. It is interesting to see what they led to. For example, question 36 of the "Traditional House" questionnaire reads as follows: "Where was the pigpen? How many pens were there? How many swine did you keep there? How was it furnished?" And there was one that led to answers concerning animals that were brought with the settlers. We can read, for example, that "the informant brought with her a swine; it was first placed in a stable for a goat, then they built up a brick pen after they demolished the previous one" (Czech woman, Staré Město). The situation described bears the marks of uncanniness: the animal is kept in a space that is not appropriate ("for a goat"). To put it in the right place means to destroy and rebuild the existing pen.

Some of the questions concerned animals that were on the farms at the time of the settlers' arrival. Like question 37 of the "Traditional House" questionnaire: "How many and what kind of farm animals were on the farm at the time of your arrival? How many did you get as an allocation for settlement? How many animals were kept by Germans?" What is striking here are two separate images: of animals 
waiting in pens as if there were no humans in the neighborhood or there being no animals at all. In both cases, interviewees also often mentioned animals that they brought with them.

The lack of particular kinds of animals could be interpreted as something strange or diminishing; while describing the state of the farm and "German" farming culture: "Where there were Germans, [there was] one goat, the informant had it even after the Germans left; they did not even have hens" (Czech woman, Stare Město). The "strangeness" of the animals that were there is explicitly stressed in the words of one of the interviewees: "She did not take anything German, and she did not want to. They handed over [German] rabbits to a pub (hospoda)" (Czech woman, Staré Město). Getting rid of "German rabbits" means making the space more "familiar." It means that what is German, including animals, is seen as "unfamiliar," "strange," and animals as such could play the role of ghosts that still remind them of the unwanted presence of someone who took care of them in the past. But these are not the only ghosts present in the expulsion landscape of the borderlands.

\section{Who is haunting}

Although sometimes one can have the feeling that the empty, ghostly landscapes of the Czech borderlands are truly empty, that is, there were no humans there and settlers came to houses that were no longer inhabited, the picture that is further developed by interviewees differ. There were already some signs of a "strange" presence: mythical "first settlers," ominous "gold-diggers," and "German" animals that needed to be taken care of. But among the "ghosts" that haunt the landscape, we can also distinguish German-speaking inhabitants that were not expelled until the late 1940s, 1950s, or that were not expelled at all.

When they came, in different villages and towns in the borderlands, settlers often had contact with "previous" or "former"-as they are described in the questionnaire-owners of the properties that they were now meant to take. Sometimes this contact was rather intimate in character: both families lived together for some time and were forced to set some rules about how to use the newly common space. It is worth seeing how "Germans" are described. In terms of ghost stories, some were described as kinds of gatekeepers that vanished as the property became "disenchanted": "[At the time of his arrival, there was] one old German woman. They didn't live together. She was expelled before the informant's family came; he had only one meeting with her, when he first came to the sawmill" (Czech man, Staré Město). The woman is old, the settler sees her only once, and then she is expelled and disappears.

One of the questions important for the researchers was question 42 of the "Traditional House" questionnaire: "How did you share a house with Germans? Where did they sleep and cook, and where was your family? How did you tolerate 
one another? Did they give you advice, for example, what to do in the house or in the farm or, contrariwise, did they try to do you any harm? If they tried to do you harm, in what way? How was it with Germans in the village at that time? Did the original German inhabitants of the house help you on the farm? How many people, who, and with what? Were there any Germans allocated to work? When, for how long, how many people?" Usually interviewees describe a situation where some rooms were still "German," and there were common spaces such as the kitchen and the bathroom:

\footnotetext{
"The Germans used one room and a kitchen. The informant used a second room; they shared a bathroom; they tolerated each other well. There was no farm" (Czech woman, Staré Město); "the Germans used to live in the attic (there was not a room built there yet); there they had two beds, a wardrobe, a table, a bedside table, a laver; they cooked together in the kitchen, they tolerated each other well, and worked only around the house; they were old, unable to move a lot (there was no farm)" (Czech woman, Staré Město); “they lived in a rent-charged space (vyměnek); they cooked and ate together with the informant's family; they tolerated each other pretty well." (Czech man with German wife, Staré Město)
}

There are two factors that should be noted here. The separation of these two worlds, a familiar "Czech" one and a "ghostly" German one, according to the settlers, is good for mutual living - the two groups "tolerate" each other well. The second factor is the space occupied by Germans: they usually live in "unpleasant" places: attics, distant rooms, or rent-charged spaces-in exile or, as I dare say, in spaces often occupied by ghosts: darker, more distant, and not very well-known or seen as habitable. They are also bound to them ("work only around the house"); they haunt them like ghosts until they are no longer there.

How they are described? In response to question 35 of "Data about informant," concerning directly mutual contacts: "If there were Germans on the property, what kind of contacts did the settlers maintain with them? Men-women-children?", the interviewees answered, that the Germans were "very obedient and 'startled'; they hadn't done anything to anyone" (Czech woman, Osoblaha); "the old German man did not do any harm" (Czech woman, Branná). They seem to be ghosts that can haunt, but they do this only by being present, not by choice. They are scary but also scared, "strange" but harmless. Seen in places but playing more a role of old ghosts that everyone is used to rather than unfriendly creatures with actual power.

But there is one more active group of "German ghosts" that haunt the landscape: they are Germans who decided to come back after they were expelled and "visit" spaces that used to be familiar to them. Already the same term "to visit" is close to the term "visitation," used when it comes to describing of the manifestation of 
a ghost. In the "Data about informant" questionnaire, there is one direct question (number 39) about these returns: "Do the Germans visit their former home? Regularly, sometimes, on some occasions? Do you maintain any relations with them?" One interviewee told researchers that "they come, but they never enter the yard; they just take photographs of the house from the outside" (Czech Volhyn woman, Osoblaha).

These returns have a lot in common with the "visitations" of ghosts. The Germans are not able to come inside; they only take photographs from some distance. They are in some space set apart, as they were when they used to live with the settlers. It is repeated by more interviewees: "They come and take photos, mainly of these less maintained buildings" (Czech woman, Staré Město); “Often enough, they are taking photographs, asking about their old house" (expatriate from Romania, woman, Branná). Their returns are seen as something ordinary: "Sometimes [they visit] (out of curiosity, how it looks here)" (German woman, Branná); "Sometimes (never here directly). Sometimes they come to see the village" (expatriate from Romania, woman, Branná). The interviewees note when the visitation does not end at the threshold of the house: "The previous owner visited a few times to see his former house, one time he was even inside" (Czech couple, Staré Město). It corresponds with the idea that ghosts are more something alive that appeared to be dead than something dead that appears to be alive (Holloway and Kneale 2008, 302).

\section{Exorcisms}

The important part of a "haunted landscape" is the possibility to "un-haunt" it, to make it more familiar, "to exorcise" it, so to speak. Ghost stories, as it was shown, have some concrete structure and most of them, at least most of the traditional ones, end in the ghosts being exorcised, the mystery being explained. Although it is sometimes hard to treat questionnaires as narrations as such, they undoubtedly lead us from one point to another, making the stories told by interviewees more coherent and structured. Therefore, it is possible to say that these stories start with a haunting (settlers coming to ruined villages with "strange," "ghostly" inhabitants) and should end with a successful exorcism and the ghost being expelled to the realm where they came from to begin with.

It is possible to say that such a scenario was planned by the researchers. It is observable in some questions, like number 46 of "Data about informant": "In what did you invest the financial resources that you gained by farm growth?-repairing farm buildings, buying tools, machines, equipment for the house, securing quality seed. Make notes on progress also after collectivization through to buying a motorcycle or auto." The emphasis is set on progress, but, as we already know, the presence of ghosts is often contrary to progress as such. 
So, what kind of actions undertaken by the settlers could be seen as exorcising the "ghostly" German space? It is interesting that holy pictures and crosses were often among the things that they brought with them:

\footnotetext{
"Yes, she does not single them out-pictures, crosses, embroidery pictures, she no longer has these objects" (Czech Volhyn woman, Osoblaha); "the mother of the informant brought some decorative objects with her from Slovakia-different pictures, a crosstoday she has nothing." (Slovak woman, Osoblaha)
}

It should be noted that they often played their role (making an "unfamiliar" space more "familiar") and disappeared from the narration ("she no longer has these objects," "today she has nothing"). When the danger passed, they were no longer needed. Some interviewees were more laconic and said only that they brought "a cross" (Czech man, Osoblaha; Czech woman, Branná). Some were able to indicate the precise location where they put it: "A cross, it hangs above the door" (Czech man, Staré Město). The cross is hung above the door: it keeps the house safe. Dark forces are not able to enter a home that is kept safe by this sign.

What was done with "haunted" German paintwork could be considered exorcism too. Interviewees recalled the following:

\footnotetext{
"Shortly after they came, they painted rooms anew-light colors, white ceilings" (Czech man, Osoblaha); "new paintwork, mainly because of cleanness" (Czech man, Staré Město); "it was painted over with lighter colors" (Czech woman, Branná); "the husband, after the house was allocated to him, even before the informant arrived, painted over the whole house." (Czech woman, Staré Město)
}

The choice of colors is meaningful: the new settlers painted over the rooms in light colors, mostly in white. What is dark should now be light. What is mysterious should be changed into something understandable. The white paint sort of elucidates, illuminates, the rooms and explains their new meaning. The world becomes understandable, ergo exorcised.

\section{Conclusions}

I would argue that, as in traditional ghost stories, the "haunted landscapes" of the borderlands became "familiar" in the process of "exorcism." But because the resettlement process was not completely successful, whole villages in the borderlands were changed into places with summer houses (chalupy), places where people do not live but only go to rest. Some exorcisms have therefore not been successful: those villages and towns are still places that are haunted by visitors from the past. That is one of the reasons why we need "spectral landscape" as a category of analysis. As it 
is brilliantly put by del Pilar Blanco and Peeren about Judith Richardson's findings, "these ghosts are an integral part of the transformations of the regions and the varied concerns that each generation brings to its environment. They demonstrate the ways in which societies look to the past-even or especially when this past is muddled - to understand the present, and to claim their own position within a given territory" (del Pilar Blanco and Peeren 2013, 484). Therefore, it seems to be of use especially in the case of post-expulsion landscapes.

I would argue that "haunted landscape" as such is a good symbolic landmark to be used in the case of the Czech borderlands and other territories that were subjected to forced migrations after World War II in Central-Eastern Europe. Similarly, as David MacWilliams came up with the term "ghost estate" in 2006 (O'Callaghan, Boyle, and Kitchins 2014, 122) as a symbolic landmark of post-economic-crisis Ireland, as related to the term applied to the previous crisis of the $19^{\text {th }}$ century: "famine village." Are there any good comparisons in the region that I have chosen? There are some topoi in Czech culture which may be seen as a counterpart to "famine village" and bear marks of "haunting" and "ghostliness." For example, descriptions of empty Czech towns during the Thirty Years' War that were emptied to avoid the Swedish invasion. The most known come from Znojmo, where inhabitants hid in the large cellars that were built under the town-the Swedish troops that came to Znojmo saw only houses that looked like someone had just disappeared from there and were too afraid to invade these "ghost towns," which ultimately evaded the ravages of war. ${ }^{5}$

The idea of "haunted landscape" can be used in a different context to explain some phenomena encountered in the borderlands. If "ghostliness in part served to articulate and contain anxieties about strange places and people" (Richardson 2003, 493), then it can be seen as a perfect tool to describe landscapes where new settlers have replaced old ones. Richardson describes the Hudson Valley, where new waves of inhabitants saw the old inhabitants and their traces in the landscape and were forced to confront them. In this sense, how the English described the Dutch and the Dutch described Native Americans is like how Czechs described Germans. New settlers become more and more conscious of the invisible forces of "otherness" (Trafton 2013, 11), which is important to understanding their particular experience of such sites. It also shows that the processes of demolition could be understood as exorcising space, an attempt to cleanse something "foreign." Demolition is then a way of "cleaning out" the space before it could be properly rebuilt. It is a sign inspiring fear as well as hope,- more than just proof of destructive human forces.

5 I would like to thank Lucie Antošíková for pointing me in this direction. 


\section{Karolina Ćwiek-Rogalska}

\section{References:}

Arburg, Adrian von, and Tomáš Staněk. 2010. Vysídleni Němcư a proměny českého pohraniči 19451951. Dokumenty z českých archivu. Díl I. Češi a Němci do roku 1945 [The Expulsion of Germans and the changes in the Czech borderlands 1945-1951. Documents from Czech archives. Part I. Czechs and Germans to the year 1945]. Úvod k edici Středokluky: Zdeněk Susa.

Bell, Michael Mayerfeld. 1997. "The Ghosts of Place." Theory and society 26, no. 6: 813-836.

Benjamin, Walter. 1999. "Thesis on the Philosophy of History." In Walter Benjamin, Illuminations, edited by Hannah Arendt, 245-255. London: Pimlico.

Bergland, Renée. 2000. The National Uncanny: Indian Ghosts and American Subjects. Lebanon: UPNE.

Briggs, Julia. 2015. "The Ghost Story." In A New Companion to the Gothic, edited by David Punter, 176185. Chichester: Wiley Blackwell.

Černý, Bohumil, Jan Křen, Václav Kural, and Milan Otahál, eds. 1990. Češi, Němci, odsun: diskuse nezavislých historiku [Czechs, Germans, expulsion: The discussion of the independent historians]. Praha: Academia.

Davies, Owen. 2016. The Haunted: A Social History of Ghosts. New York: Palgrave Macmillan. Derrida, Jacques. 2016. Widma Marksa, translated by Tomasz Załuski. Warszawa: PWN [English transl.: Specters of Marx, New York: Routledge, 1994].

Gordon, Avery. 2008. Ghostly Matters: Haunting and the Sociological Imagination. Minneapolis: University of Minnesota Press.

Hetherington, Kevin. 2004. "Secondhandedness: Consumption, Disposal and Absent Presence." Environment and Planning D: Society and Space 2, no. 2: 157-173.

Holloway, Julian, and James Kneale. 2008. "Locating Haunting: A Ghost-Hunter's Guide." Cultural Geographies 15, no. 3: 297-312.

James, Montague Rhodes. 1929. "Some Remarks on Ghost Stories by Montague Rhodes James," The Bookman, December: without page numbers.

López, Moreno E., and Blanco Z. González. 2014. "Ghost Cities and Empty Houses: Wasted Prosperity." American International Journal of Social Science 3, no. 2: 207-216.

Maddern, Jo. 2008. "Spectres of Migration and the Ghosts of Ellis Island." Cultural Geographies 15, no. 3: 359-381.

Marzec, Andrzej. 2015. Widmontologia: teoria filozoficzna i praktyka artystyczna ponowoczesności [Spectro-ontology: Philosophical theory and artistic practice]. Warszawa: Bęc Zmiana.

O'Callaghan, Cian, Mark Boyle, and Rob Kitchin. 2014. "Post-politics, Crisis, and Ireland's 'Ghost Estates'." Political Geography 42: 121-133.

Pilar Blanco, Maria del. 2012. Ghost-Watching American Modernity: Haunting, Landscape, and the Hemispheric Imagination. New York: Fordham University Press.

Pilar Blanco, Maria del, and Esther Peeren, eds. 2013. The Spectralities Reader. Ghost and Haunting in Contemporary Cultural Theory. London: Bloomsbury.

Punter, David and Glennis Byron. 2004. Gothic. Malden: Blackwell Publishing.

Richardson, Judith. 2003. Possessions: The History and Uses of Haunting in the Hudson Valley. Cambridge: Harvard University Press. 
Rosenberg, Tina. 1995. The Haunted Land: Facing Europe's Ghosts after Communism. New York: Vintage Books.

Sendyka, Roma. 2014. "Miejsca, które straszą (afekty i nie-miejsca pamięci)" [Places that scare (affects and non-places of memory)]. Teksty Drugie 1: 84-102.

Trafton, Math. 2013. The Ghostmodern: Revisionist Haunting in Turn-of-the-Century American Literature (1887-1910). Boulder: University of Colorado.

Tuan, Yi-Fu. 2013. Landscapes of Fear. Minneapolis: University of Minnesota Press.

Weinstock, Jeffrey A. 2004. Spectral America: Phantoms and the National Imagination. Madison: University of Wisconsin Press.

Wolfreys, Julian. 2001. Victorian Hauntings. London: Palgrave Macmillan.

Žižek, Slavoj. 1999. The Ticklish Subject: The Absent Centre of Political Ontology. London: Verso. 